\title{
Fishing profiles of Danish seiners and bottom trawlers in relation to current EU
} management regulations

Noack, Thomas; Frandsen, R. P.; Wieland, Kai; Krag, Ludvig Ahm; Berg, F.; Madsen, N.

Published in:

Fisheries Management and Ecology

Link to article, DOI:

$10.1111 / \mathrm{fme} .12244$

Publication date:

2017

Document Version

Peer reviewed version

Link back to DTU Orbit

Citation (APA):

Noack, T., Frandsen, R. P., Wieland, K., Krag, L. A., Berg, F., \& Madsen, N. (2017). Fishing profiles of Danish seiners and bottom trawlers in relation to current EU management regulations. Fisheries Management and Ecology, 24(6), 436-445. https://doi.org/10.1111/fme.12244

\section{General rights}

Copyright and moral rights for the publications made accessible in the public portal are retained by the authors and/or other copyright owners and it is a condition of accessing publications that users recognise and abide by the legal requirements associated with these rights.

- Users may download and print one copy of any publication from the public portal for the purpose of private study or research.

- You may not further distribute the material or use it for any profit-making activity or commercial gain

- You may freely distribute the URL identifying the publication in the public portal 


\section{Fishing profiles of Danish seiners and bottom trawlers in relation \\ 2 to current EU management regulations}

\section{Abstract}

4 Danish seines and bottom trawls operate differently and have different catching processes. Both gears

5 belong to the same legislative category in European fisheries, but different management strategies in

6 other countries and critics by fishers on grouping Danish seines and trawls together indicate disagreement

7 on current gear classification. The present study compared both gears in terms of their fishing

8 characteristics and their catches of commercial species based on 16 years of observer data. Danish

9 seining is a specialized fishing method that targeted few species, but with higher total catch rates than

10 bottom trawlers. Bottom trawling is a more all-purpose fishing method that targets a larger number of

11 species and bottom trawlers use larger engines than Danish seiners. A generalized additive mixed model

12 indicated that catch rates of flatfish are generally higher for Danish seines and catch rates of roundfish

13 species are higher for trawlers. The results do not directly suggest a separation of the gears in terms of

14 legislation as the quantities of fish below current minimum size were similar, but for example future

15 survival studies may reach different conclusions. Additional factors were found to be important in

16 determining catches of both gears.

17 KEYWORDS

18 Common Fisheries Policy, demersal fishery, discard ban, generalized additive mixed modelling,

19 landing obligation, observer data 


\section{INTRODUCTION}

21 Both Danish anchor seines and demersal otter trawls (hereafter referred to as seines and trawls,

22 respectively) are widely-used fishing gears in Denmark (total landings in 2016 by trawlers: 155917 t, by

23 seiners: 6403 t; Ministry of Environment and Food of Denmark, Danish Agrifish Agency) and many

24 other countries. Although different fishing gears are treated separately under European Union (EU)

25 regulations (e.g. beam trawls and otter trawls), seines and trawls belong to the same legislative category

26 (Council Regulation (EC) 850/98). In contrast to the EU regulations, Norwegian regulations distinguish

27 these two gears (Regulations governing the sea-fishing activities J-125-2016; Norwegian Directorate of

28 Fisheries). Owing to the differences between gear designs (e.g. lighter ground gear of seines) and

29 particularly the fishing procedures (Eigaard et al., 2016a; Herrmann, Krag, Feekings \& Noack, 2016), this grouping of seines and trawls has been brought into question by fishers and other stakeholders in the EU. Fishers that operate seines claim a loss of more marketable fish than those using trawls when legal mesh sizes are used (see Herrmann et al., 2016). This highlights the need for more detailed information about the two gear types and their catches.

Initially, the seine was developed by a Danish fisherman specifically to catch flatfish, whereas trawls are more opportunistic gears in terms of the species that they target. Today, Norway lobster (a.k.a langoustine) Nephrops norvegicus (L.) and several fish species (roundfish and flatfish) are targeted by

37 trawlers. However, a significant proportion of the catches of both gears is discarded (Kelleher, 2005).

38 This happens for several reasons including minimum landing sizes (MLS), quota restrictions and high39 grading (Catchpole et al., 2013; Feekings, Bartolino, Madsen \& Catchpole, 2012; Kelleher, 2005). In an 40 effort to eliminate discards, a central part of the new Common Fisheries Policy in Europe is a landing 41 obligation, which is being introduced on a fishery-by-fishery basis from 2016 to 2019 (Council

42 Regulations (EU) 1380/2013 and 2016/72). It applies to all species that "define the fisheries", i.e. species 43 subject to catch limits should be landed. The landing obligation further introduces minimum conservation 44 reference sizes (MCRS, usually equal to current MLS) where fish below this size are not allowed to be sold directly for human consumption (Council Regulation (EU) 1380/2013). The objective of this 
46 landing-obligation system is to make fishers be more selective (Condie, Grant \& Catchpole, 2013) and

47 to reduce bycatch instead of utilizing quota for less commercial catches (Borges, Cocas \& Nielsen, 2016).

48 However, as previous studies found indications of differences in the selectivity characteristics of seines

49 and trawls as well as larger $\mathrm{L}_{50}$ values (length at which $50 \%$ of the fish are retained) for seines for species

50 like cod Gadus morhua L. (Herrmann et al., 2016; Noack, Frandsen, Krag, Mieske \& Madsen, 2017),

51 proportions of fish below MCRS are likely different. Furthermore, differences in gear constructions (e.g.

52 lighter ground gears for seiners) might cause differences in the catches of Danish seines and bottom

53 trawls.

54 The aim of the present study was to use data from a perennial monitoring programme of 55 commercial vessels to establish a comprehensive dataset for describing and comparing the seine and 56 trawl fishery including their catches of commercial species, i.e. quota restricted species and/or species 57 that were directly targeted (for quotas and annual landings in Denmark in 2016, see Table S1). The specific objectives were to: 1) provide an insight into whether the legal grouping of seines and trawls, in terms of catches, is appropriate; 2) assess the two fishing methods in relation to the new management strategies; and 3) identify catch-related problems and challenges with which the fisheries will be confronted under the new landing-obligation system.

\section{MATERIALS AND METHODS}

\section{$63 \quad 2.1 \quad$ Data collection and selection}

64 Data for the current study originated from a national observer program (1997-2002) and a European 65 discard sampling programme (from 2002) in accordance with the European Data Directive (Council 66 Regulation (EC) 1639/2001). Data were collected during regular fishing trips (i.e. seiners were sampled 67 at daytime, trawlers were sampled at daytime and nighttime) onboard commercial fishing vessels 68 participating in the discard sampling programmes in the period from 1997 to 2012. All fishes were 69 measured for total length (TL), with Norway lobster measured for carapace length, and cephalopods 70 measured for mantle length. In cases where representative sub-samples needed to be taken, individual 
71 numbers were raised to haul level following the sampling programme's standard procedure. Fishing 72 practice was assumed to be unaffected by the presence of an observer and the chosen vessels and trips 73 were assumed to be representative for the fishery in the area (Feekings et al., 2012). Further details about 74 the Danish discard sampling programme, including sampling strategy and data collection have been 75 described in Feekings et al. (2012) and in Storr-Paulsen, Birch Håkansson, Egekvist, Degel and Dalskov 76 (2010).

77 The study area focused on Skagerrak and a small area in northern Kattegat (Fig. 1). Both areas 78 represent a relatively restricted region of large commercial importance where trawlers and seiners fish 79 under similar technical regulations. These regulations have changed several times in the past, including 80 the observed period, though the changes applied to codends in seines as well as in trawls and differences 81 between legislations in Skagerrak and Kattegat were small. Before 1989, $60 \mathrm{~mm}$ was the minimum 82 codend mesh size in both areas but increased to $70 \mathrm{~mm}$ in 1989 (Kirkegaard, Nielsen \& Bagge, 1989), 83 and a mandatory square mesh panel (SMP) was introduced in 2000 (Council Regulation (EC) 850/98).

84 From 2005, the minimum mesh size in codends was $90 \mathrm{~mm}$ (diamond mesh) or $70 \mathrm{~mm}$ (square mesh codend including a grid), respectively (Council Regulation (EC) 27/2005). Optionally, fishers were encouraged to use a $120 \mathrm{~mm}$ SMP, which has been rewarded by extra sea days (Council Regulation (EC)

87 27/2005). In 2011, the SELTRA panel comprising of either a $270 \mathrm{~mm}$ diamond mesh panel or a 180

88 SMP was made mandatory for codend mesh sizes of 90-119 mm in Kattegat (Vinther \& Eero, 2013). In

89 Skagerrak, it was introduced in 2013, but with a $140 \mathrm{~mm}$ SMP (BEK No. 1423 of 12/12/2013) instead

90 of $120 \mathrm{~mm}$. Regardless of the changes in technical regulations during the period of the sampling

91 programme, hauls with mesh sizes $<90 \mathrm{~mm}$ were excluded to use only comparable mesh sizes in the 92 analyses. Seiners never fished with these small mesh sizes, but trawlers did until the prohibition in 2005.

93 Since codend mesh size was expected to influence catches, the dataset was divided into two equalized 94 categories $(90-109 \mathrm{~mm}$ and $\geq 110 \mathrm{~mm})$. Regulations and technical measures for towed gears did not 95 only prescribe specific mesh sizes, but also additional selectivity devices like escape windows (Council 
Regulation (EC) 850/98). As the specification of these devices was not sufficiently documented in the

97 dataset, the effects of device specification have not been taken into account in the analyses.

\subsection{Description and comparison of fishing characteristics and catches}

The first part of the analysis was a general comparison of both fisheries including observation information (years of observation, number of observed vessels and number of observed hauls), characteristics of the fisheries (engine power, haul duration, fishing depth and target species) and general catch information (catch per haul, catch per hour). Where appropriate, values were calculated as mean values \pm SD and a two-way analysis of variance (ANOVA) with gear and mesh size as fixed factors followed by a Tukey-HSD test was used to test for significant differences between categories (significance level $\alpha \leq 0.05$ ).

This looked, at the species level, into the catches of commercial species i.e. species with quota in 2016 and/or explicitly targeted by the vessels considered within the dataset. After providing general information about the potential existence of quota in 2016 and potential minimum size (MS as either MLS or MCRS), information is provided about occurrence (observation frequency as number of hauls with observation divided by the number of hauls in total) and total number of caught individuals.

In addition, catch rates (number per hour) were calculated and a MS ratio (number of individuals below current MLS or potentially coming MCRS/total number of individuals per haul) was estimated for all species that have a MS. Both measures were calculated as mean values \pm SD. Testing for significant differences between the categories was done using a two-way analysis of variance (ANOVA) with gear and mesh size as fixed factors followed by a Tukey-HSD test (significance level $\alpha \leq 0.05$ ). This approach detected several significant differences between gear and mesh size categories, but $\mathrm{R}^{2}$ values were very low (Table S2, Table S3), which indicated a high unexplained deviance. To account for this and to find out which other factors than gear type and mesh size determined catch rates and MS ratios of the different species, both measurements were investigated in more detail. Models were formulated that included all additional parameters that were available from the dataset, that might be of 
121 relevance in determining catch rates and MS ratios and that could affect catches of seiners and trawlers 122 differently, i.e. depth, haul duration, latitude, longitude, subsampling factor, target species, trip number, 123 vessel name, engine power, year and year quarter. Four of them (haul duration, longitude, engine power, 124 year) had to be excluded due to collinearity with other covariates (variance inflation factors > 3; Zuur, 125 Ieno \& Elphick, 2010).

Generalized additive mixed models (GAMMs) were used to describe relationships between 127 catch rates or MS ratios and the explanatory variables to account for the unbalanced sampling design 128 between explanatory variables (e.g. different number of hauls for different gear categories). For the catch 129 rate models, a Poisson distribution was assumed because catch rate represents count data, i.e. number of 130 fish per unit of effort. Cases of over-dispersion (conditional variance exceeds the conditional mean 131 and/or presence of many zero observations) were handled using a negative binomial distribution (Zuur, 132 Ieno, Walker, Saveliev \& Smith, 2009). Both distributions were applied, using a log-link function. Zero133 observations were included into the analysis because they form an important part of the total 134 observations. Conditions on different vessels may have differed due to vessel type, vessel size, skipper 135 effects or vessel-specific sorting behaviors (Feekings, Lewy \& Madsen, 2013; Poos \& Rijnsdorp, 2007; 136 Tschernij \& Holst, 1999), but the data structure could be regarded as a hierarchical structure, i.e. vessel 137 - trip - haul. Therefore, vessel and trip were always included in the model, even if the model found them 138 to be non-significant. Furthermore, the subsampling factor was included as an offset in all models as the 139 ratio of individuals observed and individuals measured. It was the only variable which was transformed 140 (log-transformation).

141 The following was the GAMM for catch rates per haul $i$ (Eq. 2):

Catch rate $_{i} \sim$ Poisson / negative binomial $\left(\mu_{i}, \sigma\right)$, where

$$
\begin{aligned}
& \log \left(\mu_{i}\right)=\eta+\beta\left(\text { gear }_{i}\right)+\gamma\left(\operatorname{mesh}_{i}\right)+\delta\left(\text { quarter }_{i}\right)+\zeta\left(\operatorname{target}_{i}\right)+s\left(\text { depth }_{i}\right)+
\end{aligned}
$$

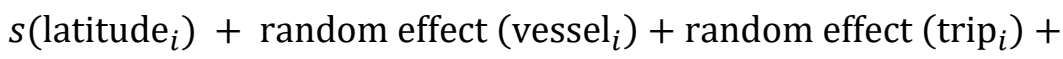

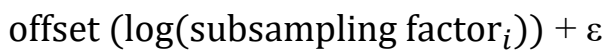



covariate "mesh" for the used numerical mesh size, the nominal covariate "quarter" for the quarters of a 146 year, the nominal covariate "target" for the targeted species and the continuous covariates "depth" and 147 "latitude" representing the fishing depth and the respective north-south position. "Vessel" and "trip" as nominal covariates are random effects that represent the respective fishing vessel and trip number. $\eta$ 149 describes the intercept, which represents seines that fished in quarter one and targeted cod, $s$ is an 150 isotropic smoothing function that was used to define smooth terms (thin-plate regression spline; Wood, $1512003)$, and $\varepsilon$ is an error term.

For MS ratios, the procedures explained for the catch rate models were followed, but since ratios can take values between 0 and 1, a binomial distribution was used. Cases of over-dispersion were handled 154 by using a quasi-binomial distribution. For both distributions, a logit-link function was applied. The GAMM for MS ratios per haul $i$ (Eq. 2) was:

MS ratio $i$ binomial / quasibinomial $\left(\mu_{i}, \sigma\right)$, where

$$
\begin{aligned}
& \operatorname{logit}\left(\frac{\mu_{i}}{1-\mu_{i}}\right)=\eta+\beta\left(\operatorname{gear}_{i}\right)+\gamma\left(\operatorname{mesh}_{i}\right)+\delta\left(\text { quarter }_{i}\right)+\zeta\left(\operatorname{target}_{i}\right)+ \\
& s\left(\text { depth }_{i}\right)+s\left(\text { latitude }_{i}\right)+\text { random effect }\left(\operatorname{vessel}_{i}\right)+\text { random effect }_{\left(\operatorname{trip}_{i}\right)+} \\
& \text { offset }\left(\log \left(\text { subsampling factor }_{i}\right)\right)+\varepsilon
\end{aligned}
$$

157

The following steps of model selection and model validation were the same for both models. After estimating the model, the least significant covariate with largest $P$-value was removed and the new model was applied again. If there were non-significant results in the categorical terms (quarter, target), then levels were combined and the model was refitted. This was done until all remaining covariates except vessel and trip were statistically significant $(P<0.05)$. The final model was validated by checking residuals for linearity and normality (scatterplot of residuals vs. fitted values and histogram), spatial independence (scatter plot of residuals vs. position as spatial factor) and still existing patterns in relation to covariates (scatter plot of residuals vs. remaining covariates). Outliers were identified in the original 
166

167

168

169

170

171

172

173

174

175

176

177

178

179

180

181

182

183

184

185

186

data and further examined, but no observations were removed since no oddities were found. Results are shown for all models, which passed all steps of the validation process.

All analyses were done in R Statistical Software (R Core Team, 2015), using the package “mgcv" (Wood, 2011) to conduct generalized additive mixed modelling.

\section{RESULTS}

\subsection{Fishing characteristics}

The dataset consisted of 285 and 460 fully-commercial hauls for seines and trawls, respectively (Table 1, Fig. 1). In relative terms, more hauls by seiners were conducted using large mesh sizes, whereas trawlers used more often smaller mesh sizes (Table 1). Mean engine power was significantly lower for seiners than for trawlers for both mesh size categories (Table 1) and mean haul duration for seiners was less than half compared to trawlers (Table 1). Areas fished by trawlers and seiners overlapped in some cases (Fig. 1), but mean fishing depth for seiners using mesh sizes $\geq 110 \mathrm{~mm}$ ("a" in Table 1) was significantly lower than for the other categories (Table 1). Mean fishing depth for seiners 90-109 mm ("b" in Table 1) and trawlers 90-109 mm ("c" in Table 1) were also significantly different, but both were not significantly different to the values for trawlers using a mesh size $\geq 110 \mathrm{~mm}$ ("bc" in Table 1). Mean total catches per haul were significantly lower for seines than for trawls, but mean catch rate for seines with mesh sizes $\geq 110 \mathrm{~mm}$ was significantly higher than for the three other categories. All target species of seiners, including plaice Pleuronectes platessa L. as the main target species, could also be found on the target list of trawlers. The list of target species for trawlers included five species that were not targeted by seines; dab Limanda limanda (L.), lemon sole Microstomus kitt (Walbaum), Norway lobster, sole Solea solea (L.) and turbot Scophthalmus maximus (L.). 


\subsection{Catches}

188 Twelve species were considered (Table 2) of which three had no quota limits in 2016 (dab, lemon sole, witch flounder Glyptocephalus cynoglossus (L.)) in the study area, but were directly targeted by some vessels. Nine of these species are subject to MS regulations, but the MCRS of Norway lobster is different to the former MLS and the MS of witch flounder is only legal on a national level in some countries (Table 2). All species were observed in both gear types and mesh categories, but occurrences of herring Clupea harengus L., Norway lobster and Norway pout Trisopterus esmarkii Nilsson were low in seines 194 (Table 2).

Mean catch rates ranged 0.0-971.2 individuals per hour (Norway lobster in both seine categories and in trawls 90-109 mm, respectively; Table 3). Regarding fish species, catch rates ranged from 0.1 (Norway pout in both seine categories) to 481.1 individuals per hour (plaice in seines $\geq 110 \mathrm{~mm}$, Table

3). Catch rates for plaice and witch flounder were significantly higher in seines and for saithe Pollachius virens (L.) and whiting Merlangius merlangus (L.) in trawls (Table 4). Catch rate was often significantly affected when Norway lobster or plaice, as main target species of the fisheries, were the targeted species (Table 4). In cases where Norway lobster was targeted, catch rates of Norway lobster and roundfish increased, but catch rates of flatfish decreased. If plaice was targeted, then catch rates of Norway lobster and roundfish decreased, but catch rates of flatfish increased. Mesh size was significant for four species (Norway lobster, saithe, whiting, witch flounder), where catch rates decreased slightly with increasing mesh size for three of them (Table 4). Season was significant for seven species (Table 4), but the differences between the four seasons were species-dependent and no general pattern was found. Water depth was found to be significant for all species and latitude was significant for seven of them (Table 4). Since latitude and water depth were handled as smooth terms, a determination of the direction of impacts has not been possible here. Vessel or trip or both random effects were significant for all species except Norway pout. except trawls $90-109 \mathrm{~mm}$, Norway lobster: trawls $\geq 110 \mathrm{~mm}$, saithe: all categories except for trawls $\geq$ 
$213110 \mathrm{~mm}$, witch flounder: seines 90-109 mm) to 50\% (Norway lobster: seines 90-109 mm and trawls

214 90-109 mm, plaice: seines $\geq 110 \mathrm{~mm}$, whiting: both seine categories, Table 3) and differences between

215 the gear and mesh categories were small (Table 5). Gear was found to have a significant effect on the

216 MS ratio of whiting (lower for trawls), and mesh size had a negative effect on the ratios of haddock

217 Melanogrammus aeglefinus (L.). Season was significant for four species (cod, dab, plaice, whiting)

218 whereby season four was often the decisive season (lower ratios). Target species significantly affected

219 ratios of four species (cod, dab, haddock, Norway lobster), where Norway lobster significantly increased

220 the ratios of cod and haddock. The smooth terms depth and latitude were significant factors for five (cod,

221 haddock, hake, whiting, witch flounder) and one species (Norway lobster), respectively. Random effects

222 were also found to be of high importance; only cod did not show any significant effects of those (Table

$2235)$.

\section{$224 \quad 4 \quad$ DISCUSSION}

225 Fishing operation and catch profiles of commercial species for seiners and trawlers fishing in the

226 Skagerrak and the northern Kattegat were compared based on 16 years of Danish observer coverage.

227 This represents a comprehensive data source to evaluate and determine how specialized and flexible the

228 two gears are in terms of target species and catches of fish below MS. The collected data is used to

229 indicate how appropriate the legislative grouping of seines and trawls is and how challenged the two

230 fisheries will be in meeting the objectives of the landing obligation.

Total catches per hour were larger for seiners using mesh sizes $\geq 110 \mathrm{~mm}$ than for trawlers.

232 Translating those to catches per swept $\mathrm{km}^{2}$ based on estimates of hourly swept area by Eigaard et al.

233 (2016b) led to similar or even higher values for trawlers (seines 90-109 mm: $161.4 \mathrm{~kg}$; seines $\geq 110 \mathrm{~mm}$ :

$234274.8 \mathrm{~kg}$; trawls 90-109 mm: $267.1 \mathrm{~kg}$; trawls $\geq 110 \mathrm{~mm}: 360.0 \mathrm{~kg}$ ). In other words, seiners are able to

235 fish on a larger area in shorter time, but trawling collects more fish from an area than seining does.

236 Higher flatfish catch rates for seiners than for trawlers and lower engine power with an expected lower

237 fuel consumption and $\mathrm{CO}_{2}$ emission, as also reported by Thrane (2004), demonstrate that seining is an 
energy efficient way of catching plaice and other flatfish species. Seiners generally fished in shallower waters than trawlers and are more restricted to flat areas to avoid damage to the seine ropes and the lighter ground gears. As a high proportion of the herding process of seines is made up by visual stimuli (seine ropes and sediment re-suspended by those), seining requires daylight to be operated efficiently. Contrary, trawlers can operate during day and night time, use sweeps which are much shorter than seine ropes and trawls are often equipped with devices like bobbins or use rockhopper ground gear designs to protect the netting from damage by rough bottoms (He \& Winger, 2010). This makes trawlers more flexible as they can operate on more diverse fishing grounds, which explains the longer list of target species for trawlers than for seiners. These differences highlight the disparity of seines and trawls. In relation to the landing obligation, this means that seiners are more vulnerable in case quotas or stocks for their few target species (mainly flatfish) are low. Contrary trawlers can shift to another target species and continue fishing more easily.

Very low $\mathrm{R}^{2}$ values in the ANOVA approach as well as the results of the GAMM approach highlighted the importance of parameters other than gear and mesh size in determining catch rates and the MS ratio. Conditional parameters such as latitude or season and random effects (vessel and/or trip) were found to have significant effects on the catches of most species. This may indicate that it is primarily not the gear or mesh size that is directly responsible for differences in MS ratios or catch rates between the two fishing methods, but more likely the specific conditions in which the gears are used. As these conditions include area and depth as factors of high importance in determining the catch rate and the proportion of fish below MLS or MCRS, differences in the catches are likely between different regions and habitat types. Although this indicates that ecological factors are likely to be underrepresented in current fishery management plans of the EU, adding more detailed area aspects and ecological conditions to future management plans might be problematic due to the diverse and complex structure of marine habitats. The unexpectedly weak effect of mesh size on catch rate and particularly MS ratio has also been observed previously using similar observer collected data. Feekings et al. (2012) were inconclusive about the importance of mesh size on the discard rates of plaice and suggested that the heterogeneity in the 

studies (Feekings et al., 2013; Poos \& Rijnsdorp, 2007; Tschernij \& Holst, 1999). There may, however,

267 be other influential factors (e.g. selective devices, quota availability) that could affect catch rates or MS ratios. Although the regulations in the study area changed several times, potential effects on catches of seines and trawls were considered to be similar because both belong to the same legislative category (Council Regulation (EC) 850/98). Nevertheless, the quality of the data collected within the observer

271 programmes could be improved by a more precise recording of additional factors like an accurate 272 description of used selective devices. The currently poor recording of the use of selective devices did not 273 allow inclusion of this factor in the analyses, and this may explain why only a weak impact of mesh size 274 was found in the present study. The relatively high number of zero observations in the dataset might be 275 reduced by increasing the sample size within the observer programme. As it could also be possible that conditional factors are linked and interact, effects of gear or mesh size were maybe confounded or masked in the present study. One way to investigate this would be studies that compare catches of seiners and trawlers under more controlled conditions. This means that additional factors such as area, depth or season should be the same for both gears and that same gear configurations (e.g. number of meshes around codend, length of codend extension, selectivity devices) are used or that analyses account for potential differences in those. catch rates between seines and trawls for several species. The results indicated that catch rates of flatfish were generally higher for seiners and catch rates for roundfish species were higher for trawlers. 285 Significant differences in MS ratios were only found for whiting, which is not directly targeted. Thus, 286 the results of the present study for fish below MS provide no clear findings to challenge the legislative 287 grouping of seines and trawls into the same category. In the context of the landing-obligation system, 288 the results indicate that both fisheries will be affected as catches of both gears were up to $50 \%$ individuals 
below MCRS, e.g. for the most important target species of both gears (Norway lobster and plaice, respectively).

Future studies that investigate survival of discards in the two fisheries may reach different conclusions if, for example, survival rates are higher for seines than for trawls. Shorter haul durations, shallower fishing grounds and smaller total catches were found in seines than in trawls. Besides the late entry of fish into the net and the corresponding short time within the gear (Herrmann et al., 2016; Noack et al., 2017), these are all factors that a have positive impact on the survivability of discarded fish (van der Reijden et al., 2017). Previous studies on discard survival focused on different types of trawling like beam trawling (Depestele, Desender, Benoît, Polet \& Vincx, 2014; Uhlmann et al., 2016; van der Reijden et al., 2017) and otter trawling (Methling, Skov \& Madsen, 2017), but no studies have so far investigated discard survival probabilities for Danish seines. Future discard survival studies should include these and compare results to trawl studies. Because temperature, storage and handling time were also found to affect survival (van der Reijden et al., 2017), these factors should be considered in such studies as well. The minor differences in MS ratios between the gears indicate that if both gears will be grouped together for the foreseeable future, challenges like the handling and storage (Sardà, Coll, Heymans \& Stergiou, 2015) or the later sale of this less valuable part of the catch are probably similar for both. To account for the mismatch in the size of caught Norway lobster and MLS (carapace length: $40 \mathrm{~mm}$ ), the MCRS is reduced to $32 \mathrm{~mm}$ carapace length. However, the approach of excluding mesh sizes $<90 \mathrm{~mm}$ in the present study in order to compare only similar mesh sizes likely ignored considerable amounts of Norway lobster and fish below MS in trawl catches. The majority of the trawl fleet in the Skagerrak/Kattegat area used mesh sizes below $90 \mathrm{~mm}$ until 2005 to fish for their main target Norway lobster, which requires the use of small mesh sizes (Krag, Frandsen \& Madsen, 2008). Today they use a mesh size of $90 \mathrm{~mm}$. The smaller fleet of seiners usually uses larger mesh sizes as they do not target Norway lobster. Mesh sizes of $120 \mathrm{~mm}$ are normally used to avoid catches of smaller fish. For flatfishtargeting active fisheries (e.g. Danish seining), an obvious way to reduce the number of small individuals in the catch could be an increase in the codend mesh size (Glass, 2000; Krag et al., 2008). As trawlers 
target different species of fish, but also crustaceans, different options are needed and increases in mesh

316 size could be supported by selective devices (e.g. escape panels or grids) as an option to exclude

317 unwanted fish (Frandsen, Holst \& Madsen, 2009; Valentinsson \& Ulmestrand, 2008). However, research

318 is still needed to improve their selective properties. The present study reveals trawling to be an

319 opportunistic and flexible fishing method, able to target several different species on a variety of different

320 substrata, whereas seining is specialised on catching primarily flatfish efficiently. Highly specialized

321 fishing gear can be challenged in fast changing biological and management systems. Contrary to trawlers,

322 seiners will not have the opportunity to switch to other fisheries in the case of low market prices or low

323 quotas. Therefore, combining the advantages of trawlers and seiners could be a conceivable approach

324 which is already recognized by the industry as several of the new fishing vessels coming into the fleet

325 are combination vessels capable of both trawling and demersal seining (Scottish seining or fly-shooting).

326 Such combination vessels give the fishers high efficiency in accessing the available fisheries and a high

327 flexibility to continuously optimize the catch composition, as needed under the new landing obligation, 328 to optimize the vessel's quota capitalization.

Another relevant point in relation to the introduction of the landing obligation is the shift from

330 a landing quota regime to a catch quota management (CQM) regime in order to reduce discards. As fish below MLS or MCRS are of lower value than larger individuals, fishing without discarding would result in lower incomes for the fishers. An analysis of the results of CQM-trials from Denmark concluded, for instance, that earnings of fishers following this system would be less compared to fishers harvesting 334 according to the conventional rules if no compensation would be given to them (Msomphora \& Aanesen, 335 2015). Compensations like extra quota or more days at sea resulted, however, in a higher gross income 336 for fishers following the new system (Msomphora \& Aanesen, 2015). The present study found Danish seining to be an efficient fishing gear for catching flatfish, which 338 is restricted to flat fishing grounds. Trawlers are more flexible in terms of fishing areas and target species 339 and catch roundfish more efficiently. Numbers of fish below MS were similar for seines and trawls, but 340 may have been different if mesh sizes $<90 \mathrm{~mm}$ would have been included in the study. Additional factors 
341 that are relevant in terms of comparing seines and trawls are the efficiency of selective devices and the 342 survivability of discards as both are likely affected by the differences (gear design, fishing procedure) 343 between both gears.

344

\section{References}

Borges, L., Cocas, L., \& Nielsen, K. N. (2016). Discard ban and balanced harvest: a contradiction? ICES Journal of Marine Science, 73, 1632-1639. doi:10.1093/icesjms/fsw065

Catchpole, T. L., Feekings, J. P., Madsen, N., Palialexis, A., Vassilopoulou, V., Valeiras, J., Garcia, T., Nikolic, N., \& Rochet, M.-J. (2013). Using inferred drivers of discarding behaviour to evaluate discard mitigation measures. ICES Journal of Marine Science, 71, 1277-1285. doi:10.1093/icesjms/fst170

Condie, H. M., Grant, A., \& Catchpole, T. L. (2013). Does banning discards in an otter trawler fishery create incentives for more selective fishing? Fisheries Research, 148, 137-146. doi:10.1016/j.fishres.2013.09.011

Depestele, J., Desender, M., Benoît, H. P., Polet, H., \& Vincx, M. (2014). Short-term survival of discarded target fish and non-target invertebrate species in the "eurocutter" beam trawl fishery of the southern North Sea. Fisheries Research, 154, 82-92. doi:10.1016/j.fishres.2014.01.018

Eigaard, O. R., Bastardie, F., Breen, M., Dinesen, G. E., Hintzen, N. T., Laffargue, P., Mortensen, L. O., Nielsen, J. R., Nilsson, H. C., O’Neill, F. G., Polet, H., Reid, D. G., Sala, A., Sköld, M., Smith, C., Sørensen, T. K., Tully, O., Zengin, M., \& Rijnsdorp, A. D. (2016a). Estimating seabed pressure from demersal trawls, seines, and dredges based on gear design and dimensions. ICES Journal of Marine Science, 73, i27-i43. doi:10.1093/icesjms/fsv099

Eigaard, O. R., Bastardie, F., Breen, M., Dinesen, G. E., Hintzen, N. T., Laffargue, P., Mortensen, L. O., Rasmus Nielsen, J., Nilsson, H., O'Neill, F. G., Polet, H., Reid, D. G., Sala, A., Sköld, M., Smith, C., Sørensen, T. K., Tully, O., Zengin, M., \& Rijnsdorp, A. D. (2016b). A correction to "Estimating seabed pressure from demersal trawls, seines and dredges based on gear design 
and dimensions". ICES Journal of Marine Science, 73, 2420-2423.

doi:10.1093/icesjms/fsw116

Feekings, J., Bartolino, V., Madsen, N., \& Catchpole, T. (2012). Fishery discards: Factors affecting their variability within a demersal trawl fishery. PLoS ONE, 7, e36409. doi:10.1371/journal.pone.0036409

Feekings, J., Lewy, P., \& Madsen, N. (2013). The effect of regulation changes and influential factors on Atlantic cod discards in the Baltic Sea demersal trawl fishery. Canadian Journal of Fisheries and Aquatic Sciences, 70, 534-542. doi:10.1139/cjfas-2012-0273

Frandsen, R. P., Holst, R., \& Madsen, N. (2009). Evaluation of three levels of selective devices relevant to management of the Danish Kattegat-Skagerrak Nephrops fishery. Fisheries Research, 97, 243-252. doi:10.1016/j.fishres.2009.02.010

Glass, C. W. (2000). Conservation of Fish Stocks through Bycatch Reduction: A Review. Northeastern Naturalist, 7, 395-410. doi:10.2307/3858520

He, P., \& Winger, P. D. (2010). Effect of trawling on the seabed and mitigation measures to reduce impact. In P. He (Ed.), Behavior of marine fishes: Capture processes and conservation challenges (pp. 295-314). Iowa: Wiley-Blackwell.

Herrmann, B., Krag, L. A., Feekings, J., \& Noack, T. (2016). Understanding and predicting size selection in diamond-mesh cod ends for Danish seining: A study based on sea trials and computer simulations. Marine and Coastal Fisheries, 8, 277-291. doi:10.1080/19425120.2016.1161682

Kelleher, K. (2005). Discards in the world's marine fisheries: An update. Rome: Food and Agriculture Organization of the United Nations.

Kirkegaard, E., Nielsen, N. A., \& Bagge, O. (1989). Mesh selection of Nephrops in 60 and $70 \mathrm{~mm}$ Nephrops trawl. Charlottenlund: Danmarks Fiskeri- og Havundersøgelser.

Krag, L. A., Frandsen, R. P., \& Madsen, N. (2008). Evaluation of a simple means to reduce discard in the Kattegat-Skagerrak Nephrops (Nephrops norvegicus) fishery: Commercial testing of 
different codends and square-mesh panels. Fisheries Research, 91, 175-186. doi:10.1016/j.fishres.2007.11.022

Methling, C., Skov, P. V., \& Madsen, N. (2017). Reflex impairment, physiological stress, and discard mortality of European plaice Pleuronectes platessa in an otter trawl fishery. ICES Journal of Marine Science, fsx004. doi:10.1093/icesjms/fsx004

Msomphora, M. R., \& Aanesen, M. (2015). Is the catch quota management (CQM) mechanism attractive to fishers? A preliminary analysis of the Danish 2011 CQM trial project. Marine Policy, 58, 78-87. doi:10.1016/j.marpol.2015.04.011

Noack, T., Frandsen, R. P., Krag, L. A., Mieske, B., \& Madsen, N. (2017). Codend selectivity in a commercial Danish anchor seine. Fisheries Research, 186, Part 1, 283-291. doi:10.1016/j.fishres.2016.10.006

Poos, J.-J., \& Rijnsdorp, A. D. (2007). An "experiment" on effort allocation of fishing vessels: the role of interference competition and area specialization. Canadian Journal of Fisheries and Aquatic Sciences, 64, 304-313. doi:10.1139/F06-177

R Core Team. (2015). R: A Language and Environment for Statistical Computing. R Foundation for Statistical Computing. Vienna. Available at: https://www.R-project.org/ (accessed 15 December 2015).

Sardà, F., Coll, M., Heymans, J. J., \& Stergiou, K. I. (2015). Overlooked impacts and challenges of the new European discard ban. Fish and Fisheries, 16, 175-180. doi:10.1111/faf.12060

Storr-Paulsen, M., Birch Håkansson, K., Egekvist, J., Degel, H., \& Dalskov, J. (2010). Danish Sampling of Commercial Fishery: Overview with special attention to discard 2010 data. DTU Aqua Report 250-2012, National Institute of Aquatic Resources, Charlottenlund. Retrieved from

Thrane, M. (2004). Energy consumption in the Danish fishery: Identification of key factors. Journal of Industrial Ecology, 8, 223-239. doi:10.1162/1088198041269427 
Tschernij, V., \& Holst, R. (1999). Evidence of factors at vessel-level affecting codend selectivity in Baltic cod demersal trawl fishery. ICES Document CM 1999/R:02. Retrieved from

Uhlmann, S. S., Theunynck, R., Ampe, B., Desender, M., Soetaert, M., \& Depestele, J. (2016). Injury, reflex impairment, and survival of beam-trawled flatfish. ICES Journal of Marine Science, 73, 1244-1254. doi:10.1093/icesjms/fsv252

Valentinsson, D., \& Ulmestrand, M. (2008). Species-selective Nephrops trawling: Swedish grid experiments. Fisheries Research, 90, 109-117. doi:10.1016/j.fishres.2007.10.011

van der Reijden, K. J., Molenaar, P., Chen, C., Uhlmann, S. S., Goudswaard, P. C., \& van Marlen, B. (2017). Survival of undersized plaice (Pleuronectes platessa), sole (Solea solea), and dab (Limanda limanda) in North Sea pulse-trawl fisheries. ICES Journal of Marine Science. doi:10.1093/icesjms/fsx019

Vinther, M., \& Eero, M. (2013). Quantifying relative fishing impact on fish populations based on spatio-temporal overlap of fishing effort and stock density. ICES Journal of Marine Science, 70, 618-627. doi:10.1093/icesjms/fst001

Wood, S. N. (2003). Thin plate regression splines. Journal of the Royal Statistical Society: Series B (Statistical Methodology), 65, 95-114. doi:10.1111/1467-9868.00374

Wood, S. N. (2011). Fast stable restricted maximum likelihood and marginal likelihood estimation of semiparametric generalized linear models. Journal of the Royal Statistical Society: Series B (Statistical Methodology), 73, 3-36. doi:10.1111/j.1467-9868.2010.00749.x

Zuur, A. F., Ieno, E. N., \& Elphick, C. S. (2010). A protocol for data exploration to avoid common statistical problems. Methods in Ecology and Evolution, 1, 3-14. doi:10.1111/j.2041210X.2009.00001.X

Zuur, A. F., Ieno, E. N., Walker, N. J., Saveliev, A. A., \& Smith, G. M. (2009). Mixed effects models and extensions in ecology with $R$. New York; London: Springer. 
442 Figure 1. Study area and location of fishing operations separated by gear and mesh size category.

443 Danish seines 90-109 mm (black dots as anchor points, $\mathrm{n}=80$ ). Danish seines $\geq 110 \mathrm{~mm}$ (white dots as 444 anchor points, $\mathrm{n}=205$ ). Demersal otter trawls 90-109 $\mathrm{mm}$ (black lines as haul tracks, $\mathrm{n}=381$ ).

445 Demersal otter trawls $\geq 110 \mathrm{~mm}$ (white lines as haul tracks, $\mathrm{n}=79$ ). Grey shading notes bathymetry of 446 the study area.

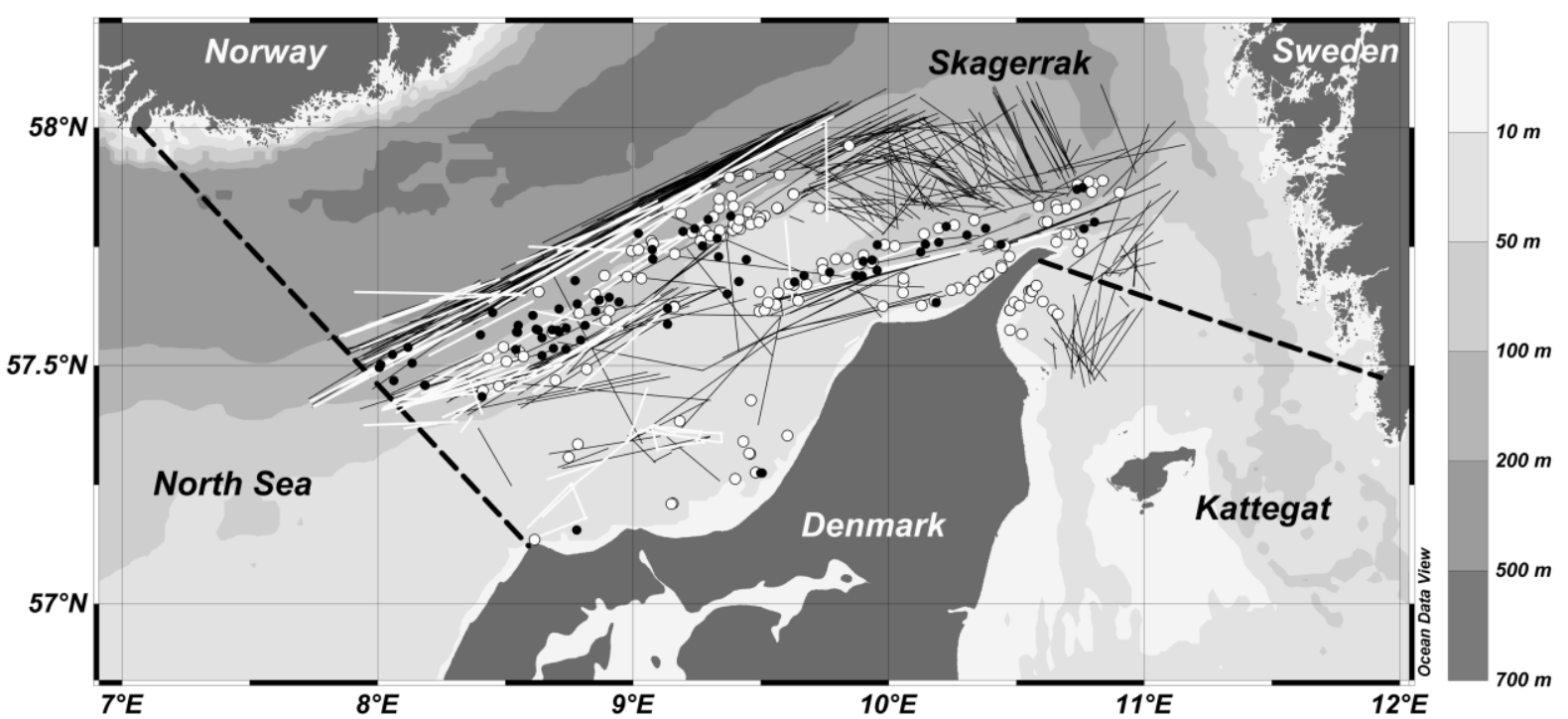


1 Table 1. General gear comparison using mean values \pm standard deviation including df (degrees of freedom) and

2 adjusted $\mathrm{R}^{2}$ as measure of explained deviance. Mean values that are not sharing a letter (a, b, c) are significantly

3 different (two-way ANOVA and post-hoc Tukey-HSD test; $\alpha \leq 0.05$ ). Target species (according to skipper) describe

4 species targeted by the different gear categories in descending order, number in parenthesis reflects number of hauls

$5 \quad$ targeting this species.

\begin{tabular}{|c|c|c|c|c|c|c|}
\hline & \multicolumn{2}{|l|}{$90-109 \mathrm{~mm}$} & \multicolumn{2}{|l|}{$\geq 110 \mathrm{~mm}$} & \multirow{2}{*}{\multicolumn{2}{|c|}{$\operatorname{adj} . R^{2}$}} \\
\hline & Seine & Trawl & Seine & Trawl & & \\
\hline Years & 11 & 16 & 14 & 11 & - & - \\
\hline Vessels (no.) & 11 & 55 & 22 & 19 & - & - \\
\hline Engine power $(\mathrm{kW})$ & $214.9 \pm 90.0 \mathrm{a}$ & $404.4 \pm 194.1 \mathrm{~b}$ & $169.6 \pm 105.2 \mathrm{a}$ & $457.2 \pm 265.5 b$ & 741 & 0.30 \\
\hline Hauls (no.) & 80 & 381 & 205 & 79 & 205 & \\
\hline Haul duration (min) & $172.0 \pm 23.9 \mathrm{a}$ & $369.7 \pm 101.2 b$ & $154.7 \pm 35.9 \mathrm{a}$ & $356.2 \pm 101.6 b$ & 741 & 0.60 \\
\hline Fishing depth (m) & $75.1 \pm 39.2 b$ & $109.2 \pm 68.1 \mathrm{c}$ & $52.4 \pm 38.0 \mathrm{a}$ & $92.3 \pm \quad 67.5 b c$ & 739 & 0.15 \\
\hline Catch per haul (kg) & $464.9 \pm 320.1 \mathrm{a}$ & $879.9 \pm 589.6 b$ & $700.5 \pm 772.5 \mathrm{a}$ & $1151.4 \pm 1527.3 \mathrm{c}$ & 741 & 0.05 \\
\hline Catch per hour (kg) & $161.4 \pm 111.2 \mathrm{a}$ & $146.9 \pm 93.8 \mathrm{a}$ & $274.8 \pm 294.6 \mathrm{~b}$ & $198.0 \pm 261.9 \mathrm{a}$ & 741 & 0.07 \\
\hline $\begin{array}{l}\text { Target species (No. } \\
\text { of hauls) }\end{array}$ & $\begin{array}{r}\text { Plaice (60) } \\
\text { Witch flounder (8) } \\
\text { Cod (7) } \\
\text { Haddock (5) }\end{array}$ & $\begin{array}{r}\text { Norway lobster (222) } \\
\text { Cod (59) } \\
\text { Saithe (32) } \\
\text { Plaice (26) } \\
\text { Witch flounder (16) } \\
\text { Sole (13) } \\
\text { Haddock (11) } \\
\text { Lemon sole (2) }\end{array}$ & $\begin{array}{r}\text { Plaice (103) } \\
\text { Cod (68) } \\
\text { Haddock (21) } \\
\text { Witch flounder (11) } \\
\text { Saithe (2) }\end{array}$ & $\begin{array}{r}\text { Plaice (37) } \\
\text { Saithe (10) } \\
\text { Cod (9) } \\
\text { Haddock (9) } \\
\text { Witch flounder (4) } \\
\text { Lemon sole (3) } \\
\text { Norway lobster (3) } \\
\text { Dab (2) } \\
\text { Turbot (2) }\end{array}$ & & \\
\hline
\end{tabular}


1 Table 2. Species overview including information about potential existence of quota in 2016, potentially

2 existing minimum size $(\mathrm{cm})$, total number of observed individuals and occurrence (ratio of hauls with

3 observation to total number of hauls) separated by gear (seine (S) and trawl (T)) and mesh size categories (in

$4 \mathrm{~mm})$.

\begin{tabular}{|c|c|c|c|c|c|c|c|c|}
\hline \multirow{3}{*}{ Species } & \multirow{3}{*}{ Scientific name } & \multirow{3}{*}{ Quota } & \multirow{3}{*}{ Minimum size $(\mathrm{cm})$} & \multirow{3}{*}{ Individuals } & \multicolumn{4}{|c|}{ Occurrence (\%) } \\
\hline & & & & & \multicolumn{2}{|c|}{$90-109$} & \multicolumn{2}{|c|}{$\geq 110$} \\
\hline & & & & & $\mathrm{S}$ & $\mathrm{T}$ & $\mathrm{S}$ & $\mathrm{T}$ \\
\hline$\overline{\mathrm{Cod}}$ & Gadus morhua L. & yes & 30 & 151964 & 98 & 96 & 88 & 91 \\
\hline Dab & Limanda limanda (L.) & no & - & 174856 & 81 & 46 & 81 & 67 \\
\hline Haddock & Melanogrammus aeglefinus (L.) & yes & 27 & 154929 & 78 & 84 & 53 & 72 \\
\hline Hake & Merluccius merluccius (L.) & yes & 30 & 13215 & 70 & 64 & 30 & 41 \\
\hline Herring & Clupea harengus L. & yes & 18 & 6399 & 9 & 37 & 6 & 22 \\
\hline Lemon sole & Microstomus kitt (Walbaum) & no & - & 24794 & 91 & 67 & 64 & 62 \\
\hline Norway lobster & Nephrops norvegicus (L.) & yes & total: 13 , carapace: $4^{1}$ & 1910743 & 1 & 72 & 1 & 14 \\
\hline Norway pout & Trisopterus esmarkii (Nilsson) & yes & - & 13425 & 4 & 30 & 6 & 9 \\
\hline Plaice & Pleuronectes platessa L. & yes & 27 & 498873 & 96 & 85 & 99 & 82 \\
\hline Saithe & Pollachius virens (L.) & yes & 30 & 54705 & 41 & 60 & 20 & 56 \\
\hline Whiting & Merlangius merlangus (L.) & yes & 23 & 46714 & 35 & 70 & 21 & 48 \\
\hline Witch flounder & Glyptocephalus cynoglossus (L.) & no & -2 & 65207 & 79 & 80 & 47 & 52 \\
\hline
\end{tabular}

$5 \quad{ }^{1}$ new: total length: 10.5 ; tail length: 5.9 ; carapace length: 3.2

62 no Minimum Landing Size (MLS) on EU level, but local MLS of $28 \mathrm{~cm}$ in Germany, Denmark, Scotland, Sweden and parts of 7 England 
1 Table 3. Catch rates (ind./h) and minimum size (MS) ratios (individuals below minimum landing size (MLS) or

2 minimum conservation reference size (MCRS)/total no. of individuals) \pm SD separated by gear and mesh size.

\begin{tabular}{|c|c|c|c|c|c|c|c|c|}
\hline \multirow{3}{*}{ Species } & \multicolumn{4}{|l|}{ Catch rate } & \multicolumn{4}{|l|}{ MS ratio } \\
\hline & \multicolumn{2}{|l|}{$90-109 \mathrm{~mm}$} & \multicolumn{2}{|l|}{$\geq 110 \mathrm{~mm}$} & \multicolumn{2}{|c|}{ 90-109 mm } & \multicolumn{2}{|l|}{$\geq 110 \mathrm{~mm}$} \\
\hline & Seine & Trawl & Seine & Trawl & Seine & Trawl & Seine & Trawl \\
\hline$\overline{\text { Cod }}$ & $47.7 \pm 48.3$ & $38.3 \pm 51.9$ & $54.2 \pm 109.2$ & $47.2 \pm 64.4$ & $0.2 \pm 0.2$ & $0.4 \pm 0.3$ & $0.3 \pm 0.3$ & $0.1 \pm 0.2$ \\
\hline Dab & $38.3 \pm 75.8$ & $51.8 \pm 127.2$ & $74.6 \pm 178.2$ & $40.9 \pm 142.1$ & - & - & - & - \\
\hline Haddock & $38.3 \pm 47.5$ & $40.9 \pm 82.8$ & $33.1 \pm 76.8$ & $62.2 \pm 115.2$ & $0.1 \pm 0.2$ & $0.4 \pm 0.4$ & $0.2 \pm 0.3$ & $0.1 \pm 0.2$ \\
\hline Hake & $2.6 \pm 5.6$ & $5.0 \pm \quad 10.2$ & $1.9 \pm 8.0$ & $1.1 \pm \quad 2.2$ & $0.0 \pm 0.0$ & $0.2 \pm 0.3$ & $0.0 \pm 0.0$ & $0.0 \pm 0.1$ \\
\hline Herring & $0.2 \pm \quad 0.7$ & $2.5 \pm$ & $0.3 \pm 2.1$ & $1.0 \pm$ & $0.2 \pm 0.4$ & $0.1 \pm 0.3$ & $0.4 \pm 0.4$ & $0.2 \pm 0.3$ \\
\hline Lemon sole & $14.6 \pm 14.5$ & $6.4 \pm \quad 21.1$ & $5.1 \pm 12.3$ & $8.2 \pm 14.6$ & - & - & - & - \\
\hline Norway lobster & $0.0 \pm \quad 0.2$ & $971.2 \pm 1952.0$ & $0.0 \pm \quad 0.0$ & $30.2 \pm 153.5$ & $0.5 \pm 0.0$ & $0.5 \pm 0.3$ & $0.0 \pm 0.0$ & $0.3 \pm 0.3$ \\
\hline Norway pout & $0.1 \pm \quad 0.8$ & $5.3 \pm 27.1$ & $0.1 \pm \quad 0.8$ & $0.5 \pm \quad 2.7$ & - & - & - & - \\
\hline Plaice & $280.1 \pm 689.7$ & $60.3 \pm 148.4$ & $481.1 \pm 849.7$ & $146.1 \pm 194.1$ & $0.2 \pm 0.2$ & $0.4 \pm 0.4$ & $0.5 \pm 0.4$ & $0.3 \pm 0.4$ \\
\hline Saithe & $2.7 \pm 14.0$ & $15.3 \pm 49.1$ & $3.9 \pm 44.6$ & $22.5 \pm 82.8$ & $0.0 \pm 0.1$ & $0.0 \pm 0.1$ & $0.0 \pm 0.2$ & $0.1 \pm 0.2$ \\
\hline Whiting & $0.9 \pm \quad 2.2$ & $20.8 \pm 37.1$ & $1.1 \pm 4.3$ & $4.1 \pm$ & $0.5 \pm 0.4$ & $0.4 \pm 0.3$ & $0.5 \pm 0.4$ & $0.1 \pm 0.2$ \\
\hline Witch flounder & $33.2 \pm 63.1$ & $17.1 \pm 30.7$ & $17.4 \pm 45.2$ & $6.7 \pm 11.5$ & $0.0 \pm 0.0$ & $0.2 \pm 0.3$ & $0.1 \pm 0.2$ & $0.0 \pm 0.1$ \\
\hline
\end{tabular}


1 Table 4. Model results for catch rates (log-transformed) including significance levels. Smooth terms and random terms given as estimated degrees of

2 freedom (edf).

3

\begin{tabular}{|c|c|c|c|c|c|c|c|c|c|c|}
\hline \multirow{3}{*}{ Species } & \multirow{3}{*}{$\eta$} & \multicolumn{8}{|l|}{ Predictors } & \multirow{3}{*}{$\begin{array}{l}\text { Explained } \\
\text { deviance } \\
(\%)\end{array}$} \\
\hline & & \multicolumn{4}{|c|}{ Categorical term estimates } & \multicolumn{2}{|c|}{ Smooth term (edf) } & \multicolumn{2}{|c|}{ Random term (edf) } & \\
\hline & & Gear (trawl) & Mesh & Season & Target & Depth & Latitude & Vessel & Trip & \\
\hline Cod & $2.3 * * *$ & & & & Plaice $(-0.5)^{* * *}$ & $2.8 * * *$ & $7.6^{* * * *}$ & $34.2 * * *$ & $128.8 * * *$ & 72.1 \\
\hline $\mathrm{Dab}$ & $0.3^{*}$ & & & & $\operatorname{Dab}(5.3)^{* *}$ & $2.9 * * *$ & $4.4 * * *$ & $36.1 *$ & $112.7 * *$ & 88.9 \\
\hline Haddock & $0.6 * * *$ & & & $4(0.5) *$ & & $3.0 * * *$ & & $38.3 * *$ & $133.2 * *$ & 87.0 \\
\hline Hake & $-3.1 * * *$ & & & $\begin{array}{l}2(1.5)^{* * *} \\
3(1.9)^{* * *} \\
4(1.8)^{* * *}\end{array}$ & $\begin{array}{c}\text { Haddock }(-0.6)^{* *} \\
\text { Norway lobster }(1.1)^{* * *}\end{array}$ & $1.0 * * *$ & $9.0 * *$ & 58.7 & $128.9 *$ & 88.7 \\
\hline Herring & $-1.9 * * *$ & & & $3(-1.6) *$ & Plaice $(-2.7) * * *$ & $2.4 * *$ & & 25.7 & $83.1 *$ & 91.3 \\
\hline Lemon sole & 0.1 & & & $2(0.6) * *$ & $\begin{array}{c}\text { Dab }(3.2)^{*} \\
\text { Norway lobster }(-1.4)^{* * *} \\
\text { Saithe }(-1.3)^{*}\end{array}$ & $2.8 * * *$ & $4.8^{* *}$ & 21.9 & $93.5^{* * *}$ & 77.8 \\
\hline Norway lobster & $14.7 * * *$ & & $-0.1 * * *$ & & $\begin{array}{r}\text { Haddock }(-1.8)^{* *} \\
\text { Norway lobster }(2.2)^{* * *} \\
\text { Plaice }(-3.9)^{* * *}\end{array}$ & $2.5^{* * *}$ & & $50.3 * *$ & $85.2 * *$ & 97.7 \\
\hline Norway pout & $-4.9 * * *$ & & & & Norway lobster $(1.5)^{* * *}$ & $3.0 * * *$ & $7.8 * * *$ & 49.4 & 63.2 & 89.6 \\
\hline Plaice & $2.9 * * *$ & $-0.9 * * *$ & & $4(-0.6)^{* * *}$ & $\begin{array}{r}\text { Dab }(3.7)^{* * *} \\
\text { Norway lobster }(-0.7)^{* * *} \\
\text { Plaice }(0.5)^{* * *}\end{array}$ & $2.8 * * *$ & & 34.3 & $127.3^{*}$ & 92.3 \\
\hline Saithe & $-5.9 * * *$ & $1.1^{* *}$ & $0.0^{*}$ & $\begin{array}{l}2(1.5) * * * \\
3(1.3)^{* * *} \\
4(1.3)^{* * *}\end{array}$ & & $2.8 * * *$ & $1.4^{*}$ & 0.0 & $123.5^{* * *}$ & 92.6 \\
\hline Whiting & $5.0^{* *}$ & $1.2 *$ & $-0.0^{*}$ & $\begin{array}{l}2(-2.0)^{* * *} \\
3(-1.3) * * * \\
4(-0.8) * * *\end{array}$ & Plaice $(-1.7)^{* * *}$ & $2.7 * * *$ & & 36.6 & $128.0 *$ & 89.8 \\
\hline Witch flounder & $4.5 * * *$ & $-1.3 * * *$ & $-0.0 * * *$ & & Witch flounder $(0.5)^{*}$ & $2.9 * * *$ & $2.1^{*}$ & 13.6 & $111.3 * * *$ & 85.3 \\
\hline
\end{tabular}

Significance levels: $* P<0.05, * * P<0.01, * * * P<0.001 ; \eta=$ intercept (gear: Danish seine, season: 1 , target: cod) 
1 Table 5. Model results for minimum size ratio (individuals below minimum landing size or minimum conservation reference size/total no. of

2 individuals, logit-transformed) including significance levels. Smooth terms and random terms given as estimated degrees of freedom (edf).

\begin{tabular}{|c|c|c|c|c|c|c|c|c|c|c|}
\hline \multirow{3}{*}{ Species } & \multirow{3}{*}{$\eta$} & \multicolumn{8}{|l|}{ Predictors } & \multirow{3}{*}{$\begin{array}{l}\text { Explained } \\
\text { deviance } \\
(\%)\end{array}$} \\
\hline & & \multicolumn{4}{|c|}{ Categorical term estimates } & \multicolumn{2}{|c|}{ Smooth term (edf) } & \multicolumn{2}{|c|}{ Random term (edf) } & \\
\hline & & Gear (trawl) & Mesh & Season & Target & Depth & Latitude & Vessel & Trip & \\
\hline Cod & $-1.6 * * *$ & & & $4(-1.1)^{* * *}$ & Norway lobster $(0.6)^{*}$ & $3.0^{* *}$ & & 80.3 & 117.2 & 72.0 \\
\hline Haddock & 2.1 & & $-0.0 *$ & & $\begin{array}{c}\text { Norway lobster }(1.2)^{* * *} \\
\text { Saithe }(1.4)^{* *}\end{array}$ & $2.2 * *$ & & $24.0 * * *$ & 12.3 & 45.8 \\
\hline Hake & -5.3 & & & & & $2.0 * *$ & & 61.2 & $74.0 *$ & 89.9 \\
\hline Norway lobster & $-0.7^{*}$ & & & & $\begin{array}{c}\text { Haddock }(-1.3)^{*} \\
\text { Norway lobster }(-1.2)^{* * *} \\
\text { Saithe }(-0.9)^{*} \\
\text { Witch flounder }(-1.8)^{* * *}\end{array}$ & & $1.0^{* *}$ & $35.7 * * *$ & 32.6 & 64.7 \\
\hline Plaice & $-1.9 * * *$ & & & $4(-1.2) * *$ & & & & $80.6^{*}$ & $116.9 * *$ & 78.6 \\
\hline Whiting & $-1.0 * *$ & $-1.0^{*}$ & & $\begin{array}{c}2(1.0)^{* *} \\
4(-1.1)^{* *}\end{array}$ & & $1.2 * *$ & & 21.9 & $69.4^{*}$ & 67.7 \\
\hline Witch flounder & $-3.9 * *$ & & & & & $1.0 * *$ & & 69.1 & $113.1 * * *$ & 89.4 \\
\hline
\end{tabular}

3 Significance levels: $* P<0.05, * * P<0.01,{ }^{* * *} P<0.001, \eta=$ intercept (gear: Danish seine, season: 1 , target: cod) 


\section{Supplementary material}

2 Table S1. Quota in Skagerrak-Kattegat area (Ministry of Environment and Food of Denmark, Danish Agrifish

3 Agency) and total annual landings ( $\mathrm{t}$ ) of commercial species in Denmark for 2016.

\begin{tabular}{|c|c|c|c|}
\hline \multirow{2}{*}{ Species } & \multirow{2}{*}{ Quota in Kattegat/Skagerrak (t) } & \multicolumn{2}{|c|}{ Total annual landings in Denmark } \\
\hline & & Bottom trawls & Danish seines \\
\hline Cod & Kattegat: 233; Skagerrak: 3747 & 15584 & 941 \\
\hline Dab & - & 779 & 294 \\
\hline Haddock & 3400 & 1233 & 334 \\
\hline Hake & 1334 & 1739 & 109 \\
\hline Herring & 16538 & 664 & 0 \\
\hline Lemon sole & - & 1122 & 35 \\
\hline Norway lobster & 8513 & 4088 & 0 \\
\hline Norway pout & $99907 *$ & 19627 & 0 \\
\hline Plaice & Kattegat: 2089; Skagerrak: 9234 & 15356 & 4392 \\
\hline Saithe & $4091^{*}$ & 3238 & 7 \\
\hline Whiting & 926 & 309 & 13 \\
\hline Witch flounder & - & 1239 & 164 \\
\hline
\end{tabular}

$4 \quad$ incl. North Sea

5 Table S2. Catch rate (individuals $/ \mathrm{h}$ ) as mean value \pm standard deviation including $\mathrm{df}$ (degrees of freedom) and

6 adjusted $\mathrm{R}^{2}$ as measure of explained deviance. Mean values that are not sharing a letter (a, b, c) are significantly

7 different (two-way ANOVA and post-hoc Tukey-HSD test; $\alpha \leq 0.05$ ).

\begin{tabular}{|c|c|c|c|c|c|c|}
\hline \multirow{3}{*}{ Species } & \multicolumn{4}{|l|}{ Catch rate } & \multirow{3}{*}{ df } & \multirow{3}{*}{$\begin{array}{l}\text { adj. } \\
\mathrm{R}^{2}\end{array}$} \\
\hline & \multicolumn{2}{|l|}{$90-109 \mathrm{~mm}$} & \multicolumn{2}{|l|}{$\geq 110 \mathrm{~mm}$} & & \\
\hline & Seine & Trawl & Seine & Trawl & & \\
\hline Cod & $47.7 \pm 48.3 \mathrm{a}$ & $38.3 \pm 51.9 a$ & $54.2 \pm 109.2 \mathrm{a}$ & $47.2 \pm 64.4 \mathrm{a}$ & 741 & 0.00 \\
\hline $\mathrm{Dab}$ & $38.3 \pm 75.8 \mathrm{a}$ & $51.8 \pm 127.2 \mathrm{a}$ & $74.6 \pm 178.2 \mathrm{a}$ & $40.9 \pm 142.1 \mathrm{a}$ & 741 & 0.00 \\
\hline Haddock & $38.3 \pm 47.5 \mathrm{ab}$ & $40.9 \pm \quad 82.8 \mathrm{ab}$ & $33.1 \pm 76.8 \mathrm{a}$ & $62.2 \pm 115.2 b$ & 741 & 0.01 \\
\hline Hake & $2.6 \pm 5.6 \mathrm{ab}$ & $5.0 \pm 10.2 \mathrm{~b}$ & $1.9 \pm$ & $1.1 \pm 2.2 \mathrm{a}$ & 741 & 0.03 \\
\hline Herring & $0.2 \pm \quad 0.7 \mathrm{a}$ & $8.0 \mathrm{~b}$ & $0.3 \pm$ & $1.0 \pm \quad 4.1 \mathrm{ab}$ & 741 & 0.03 \\
\hline Lemon sole & $14.6 \pm 14.5 b$ & $6.4 \pm \quad 21.1 \mathrm{a}$ & $5.1 \pm 12.3 \mathrm{a}$ & $8.2 \pm 14.6 \mathrm{ab}$ & 741 & 0.02 \\
\hline Norway lobster & $0.0 \pm \quad 0.2 \mathrm{a}$ & $971.2 \pm 1952.0 \mathrm{~b}$ & $0.0 \pm$ & $30.2 \pm 153.5 \mathrm{a}$ & 741 & 0.10 \\
\hline Norway pout & $0.1 \pm \quad 0.8 \mathrm{ab}$ & $5.3 \pm 27.1 \mathrm{a}$ & $0.1 \pm$ & $0.5 \pm \quad 2.7 \mathrm{ab}$ & 741 & 0.01 \\
\hline Plaice & $280.1 \pm 689.7 b$ & $60.3 \pm 148.4 \mathrm{a}$ & $481.1 \pm 849.7 \mathrm{c}$ & $146.1 \pm 194.1 \mathrm{ab}$ & 741 & 0.11 \\
\hline Saithe & $2.7 \pm 14.0 \mathrm{ab}$ & $15.3 \pm 49.1 \mathrm{~b}$ & $3.9 \pm 44.6 \mathrm{a}$ & $22.5 \pm 82.8 b$ & 741 & 0.01 \\
\hline Whiting & $0.9 \pm$ & $20.8 \pm 37.1 \mathrm{~b}$ & $1.1 \pm$ & $4.1 \pm 9.1 \mathrm{a}$ & 741 & 0.11 \\
\hline Witch flounder & $33.2 \pm 63.1 \mathrm{~b}$ & $17.1 \pm \quad 30.7 \mathrm{a}$ & $17.4 \pm \quad 45.2 \mathrm{a}$ & $6.7 \pm 11.5 \mathrm{a}$ & 741 & 0.02 \\
\hline
\end{tabular}


9 Table S3. Minimum size (MS) ratio (individuals below minimum landing size (MLS) or minimum conservation

10 reference size (MCRS)/total no. of individuals) \pm standard deviation including df (degrees of freedom) and

11 adjusted $\mathrm{R}^{2}$ as measure of explained deviance. Mean values that are not sharing a letter (a, $\left.\mathrm{b}, \mathrm{c}\right)$ are significantly

12 different (two-way ANOVA and post-hoc Tukey-HSD test; $\alpha \leq 0.05$ ).

\begin{tabular}{|c|c|c|c|c|c|c|}
\hline \multirow{3}{*}{ Species } & \multicolumn{4}{|l|}{ MS ratio } & \multirow{3}{*}{$\mathrm{df}$} & \multirow{3}{*}{$\operatorname{adj.} \mathrm{R}^{2}$} \\
\hline & \multicolumn{2}{|l|}{$90-109 \mathrm{~mm}$} & \multicolumn{2}{|l|}{$\geq 110 \mathrm{~m}$} & & \\
\hline & Seine & Trawl & Seine & Trawl & & \\
\hline Cod & $0.2 \pm 0.2 \mathrm{ab}$ & $0.4 \pm 0.3 \mathrm{c}$ & $0.3 \pm 0.3 \mathrm{~b}$ & $0.1 \pm 0.2 \mathrm{a}$ & 693 & 0.08 \\
\hline Haddock & $0.1 \pm 0.2 \mathrm{a}$ & $0.4 \pm 0.4 \mathrm{~b}$ & $0.2 \pm 0.3 \mathrm{a}$ & $0.1 \pm 0.2 \mathrm{a}$ & 543 & 0.17 \\
\hline Hake & $0.0 \pm 0.0 \mathrm{a}$ & $0.2 \pm 0.3 b$ & $0.0 \pm 0.0 \mathrm{a}$ & $0.0 \pm 0.1 \mathrm{a}$ & 388 & 0.11 \\
\hline Herring & $0.2 \pm 0.4 \mathrm{a}$ & $0.1 \pm 0.3 \mathrm{a}$ & $0.4 \pm 0.4 \mathrm{a}$ & $0.2 \pm 0.3 \mathrm{a}$ & 173 & 0.02 \\
\hline Norway lobster & $0.5 \pm 0.0 \mathrm{ab}$ & $0.5 \pm 0.3 b$ & $0.0 \pm 0.0 \mathrm{a}$ & $0.3 \pm 0.3 \mathrm{a}$ & 284 & 0.04 \\
\hline Plaice & $0.2 \pm 0.2 \mathrm{a}$ & $0.4 \pm 0.4 b c$ & $0.5 \pm 0.4 \mathrm{c}$ & $0.3 \pm 0.4 \mathrm{ab}$ & 664 & 0.05 \\
\hline Saithe & $0.0 \pm 0.1 \mathrm{a}$ & $0.0 \pm 0.1 \mathrm{a}$ & $0.0 \pm 0.2 \mathrm{a}$ & $0.1 \pm 0.2 \mathrm{a}$ & 345 & 0.00 \\
\hline Whiting & $0.5 \pm 0.4 \mathrm{~b}$ & $0.4 \pm 0.3 b$ & $0.5 \pm 0.4 \mathrm{~b}$ & $0.1 \pm 0.2 \mathrm{a}$ & 372 & 0.06 \\
\hline Witch flounder & $0.0 \pm 0.0 \mathrm{a}$ & $0.2 \pm 0.3 \mathrm{~b}$ & $0.1 \pm 0.2 \mathrm{a}$ & $0.0 \pm 0.1 \mathrm{a}$ & 501 & 0.14 \\
\hline
\end{tabular}

